SULUH Jurnal Bimbingan Konseling, April 2017, Volume 3 Nomor 1 (42-47)

http://jurnal.umpalangkaraya.ac.id/ejurnal/suluh

\title{
PEMILIHAN LAYANAN PENEMPATAN DAN PENYALURAN DALAM PEMILIHAN JURUSAN PESERTA DIDIK KELAS XI DI SMA MUHAMMADIYAH 1 PALANGKA RAYA
}

\author{
Oleh \\ Normalasari, M. Andi Setiawan
}

\begin{abstract}
ABSTRAK
Penelitian ini merupakan penelitian studi kasus survey deskriptif yang diartikan sebagai penelitian yang dilakukan dengan tujuan semata - mata memberikan gambaran tentang sesuatu. Selain itu juga dapat diartikan sebagai proses pemecahan masalah yang diselidiki dengan melukiskan keadaan subjek dan objek penelitian pada saat sekarang berdasarkan fakta - fakta yang tampak atau sebagaimana adanya, di sekolah SMA Muhammadiyah 1 Palangka Raya guru bimbingan konseling memberikan informasi yang yang cukup baik kepada peserta didiknya, dalam memberikan layanan bimbingan konseling terutama layanan penempatan dan penyaluran dalam pemilihan jurusan. Kendalanya guru BK tersebut jarng masuk kelas apalagi kalau ada mahasiswa jurusan bimingan konseling yang PPL.

Kegiatan ini dilakukan dengan menggunakan survey langsung di SMA Muhammadiyah 1 Palangka Raya dan wawancara dengan 3 orang peserta didik, 2 orang guru bimbingan konseling dan 1 orang kepala sekolah yang dilaksanakan oleh peneliti untuk mengungkap hasil secara benar dan nyata peneliti menggunakan dokumentasi lapangan sebagai pendukung data yang diperlukan seperti dokumentasi tertulis, catatan lapangan, catatan harian yang berhubungan dengan subjek penelitian serta lampiran daftar gambar.
\end{abstract}

(C) Universitas Muhammadiyah Palangkaraya

\section{PENDAHUUAN}

Dalam keseluruhan proses pendidikan di sekolah, merupakan suatu kegiatan belajar yang pokok dan penting dalam kehidupan. Jadi, berhasil atau tidaknya pencapaian tujuan pendidikan banyak bergantung bagaimana cara proses belajar yang dialami oleh peserta didik sebagai peserta didik. Belajar sudah banyak dikemukakan oleh para ahli termasuk ahli psikologi pendidikan bahwa secara psikologi belajar merupakan suatu proses perubahan tingkah laku sebagai hasil dari interaksi dengan lingkungannya, dalam mememuhi kebutuhan hidupnya. Sama halnya dengan pemilihan layanan penempatan dan penyaluran dalam jurusan peserta didik kelas XI di SMA Muhammadiyah 1 Palangka Raya (studi kasus). Titik berat pembangunan dalam pendidikan berada pada peningkatan mutu disetiap jenjang dan jenis pendidikan sebagai 
salah satu bimbingan pengembangan pemilihan layanan penempatan dan penyaluran dalam jurusan peserta didik supaya tidak ada yang merasa kerugian dan dirugikan antara peserta didik dan bimbingan konseling. pemilihan layanan penempatan dan penyaluran adalah suatu kegiatan yang dilakukan pada bagian aspek-aspek tentang teknik pengumpulan data, baik teknik tes dan non tes. Tujuan dari kegiatan ini berkaitan dengan fungsi pemahaman dalam bimbingan konseling agar guru (konselor) dapat mengumpul data tentang keterangan peserta didik (konseli) selengkap mungkin, sehingga demikian guru pembimbing akan terarah dalam memberikan layanan bimbingan konseling.

Menurut Syamsu Yusuf L.N dan A.Juntika Nurishan (2012 :15) mengemukakan bahwa pemberian layanan bimbingan adalah agar individu dapat merencanakan kegiatan penyelesaian studi perkembangan karir serta kehidupan dimasa yang akan datang, mengembangkan seluruh potensi dan kekuatan yang dimilikinya, menyesuaikan diri dengan lingkungan pendidikan, lingkungan masyarakat dan lingkungan kerja nantinya, serta mengatasi hambatan dan kesulitan yang dihadapi dalam studi penyesuaian lingkungan pendidikan maupun lingkungan kerja nantinya

Pada pelaksanaan bimbingan dan konseling di sekolah, pemilihan layanan penempatan dan penyaluran merupakan salah satu layanan dari sembilan layanan bimbingan konseling.

Prayitno (2004:99), menjelaskan bahwa layanan BK mencakup sembilan jenis layanan, yaitu:1) Layanan Orientasi, 2) Layanan Informasi, 3) Layanan Penempatan dan Penyaluran, 4) Layanan Penguasaan Konten, 5) Layanan Konseling Individual, 6) Layanan Bimbingan Kelompok, 7) Layanan Konseling Kelompok, 8) Layanan Mediasi, dan 9) Layanan Konsultasi

Layanan penempatan dan penyaluran merupakan salah satu layanan dalam bimbingan dan konseling agar dapat membantu peserta didik untuk menghindari ketidak sesuaian antara potensi dan kondisi diri yang ada pada peserta didik tersebut dan dapat berjalan secara optimal. Menurut Prayitno (2004: 2), multadi (2003: 26) layanan penempatan adalah: suatau kegiatan bimbingan yang dilakukan untuk membantu individu atau kelompok yang mengalami mismatch (ketidaksesuaian antara potensi dan dengan usaha pengembangannya), serta penempatan individu pada lingkungan yang cocok bagi dirinya serta pemberian kesempatan kepada individu untuk berkembang secara optimal.Purwoko (2008: 59) menjelaskan bahwa layanan penempatan dan penyaluran adalah serangkaian kegiatan bantuan yang diberikan kepada konseli agar dapat menempatkan dan menyalurkan segala potensi pada kondisi yang sesuai.

Layanan penempatan dan penyaluran merupakan layanan bimbingan dan konseling yang memungkinkan peserta didik memperoleh penempatan dan penyaluran yang tepat (misalnya penempatan dan penyaluran di dalam kelas, kelompok belajar, jurusan atau 
program studi, program latihan, magang, kegiatan kolektra kurikuler) sesuai dngan potensi bakat dan minat serta pribadi kondisinya.

Fenomena yang saat terjadi pada SMA Muhammadiyah 1 PalangkaRaya masih dijumpai peserta didik yang kurang cocok atau kurang sesuai pilihan jurusan dengan apa yang ada di hati sehingga menimbulkan dampak pada keseharian peserta didik di sekolah yang kurang semangat. Selain itu peserta didik belum memahami keberadaaan bimbingan dan konsleing sehingga ketika akan mengambil jurusan tanpa kesepakatan dengan guru BK.

Mendasarkan pada kondisi tersebut peneliti merasa butuh untuk mengkaji lebih dalam mengenai layanan penempatan dan penyaluran dalam pemilihan jurusan, seperti mengetahui faktor-faktor apa saja yang mempengaruhi pelaksanaan layanan penempatan penyaluran dalam pemilihan jurusan peserta didik.

\section{METODE PENELITIAN}

Metode merupakan hal yang sangat penting dalam penelitian sebab tanpa adanya metode penelitian yang dilakukan tidak dapat dipertanggungjawabkan secara ilmiah. Berdasarkan permasalahan yang diteliti maka di dalam penelitian ini peneliti menggunakan pendekatan kualitatif dengan desain penelitian Studi kasus.Studi kasus menurut Robert K. Yin (2008: 1) merupakan sebuah metode yang mengacu pada penelitian yang mempunyai unsur how dan why pada pertanyaan utama penelitiannya dan meneliti masalah-masalah kontemporer (masa kini) serta sedikitnya peluang peneliti dalam mengontrol peristiwa (kasus) yang diteliti.

Studi kasus sendiri, menurut Robert K. Yin dibagi kedalam tiga tipe yakni studi kasus eksplanatoris, eksploratoris dan deskriptif. Ketiga tipe ini berdasarkan kepada jenis dan tujuan dari pertanyaan penelitian. Penelitian eksplanatoris adalah menjelaskan suatu fenomena sosial khusus tentang mengapa (why) dan bagaimana (how) sesuatu terjadi.

Teknik pengumpul data dan Instrumenpengumpulan data dalam penelitian ini adalah observasi, wawancara,dan dokumentasi. subjek penelitian ini adalah kepala sekolah SMA Muhammadiyah 1 Palangkaraya atau yang mewakili, guru BK dan 3 orang peserta didik kelas XII. Dua (2) diantarannya jurusan IPS dan satu (1) orang jurusan IPA.

\section{HASIL DAN PEMBAHASAN}

Berdasarkan hasil penelitian yang menurut penjelasan yang disampaikan Kepala sekolah atau yang mewakili kepada peneliti pada saat wawancara bahwa dengan adanya guru BK sangat membantu sekolah ini guna dalam proses belajar mengajar atau dalam melaksanakan pemberian layanan bimbingan dan konseling di SMA Muhammadiyah 1 Palangka Raya, guru BK juga melaksanakan tugasnya dengan baik memberikan layanan penempatan dan penyaluran untuk membantu individu atau kelompok yang mengalami ketidaksesuaian antara potensi dan usaha pengembangan 
penempatan individu pada lingkungan sekolah maupun lingkungan luar yang cocok bagi diri mereka serta pemberian kesempatan kepada individu untuk berkembang secara optimal supaya peserta didik dapat menerima bimbingan dan layanan dengan baik supaya peserta didik lebih mudah nantinya untuk memilih suatu jurusan,atau studi serta karir yang akan mereka pilih sesuai dengan keinginan mereka supaya mereka juga bisa mengembangkan bakat, minat serta hoby yang ada dalam dirinya terutama kepada peserta didik yang bakat, minat dan hoby yang pada saat ini sudah berjalan dengan baik.

1. Peran guru BK

Guru BK melaksanakan layanan bimbingan dan konseling bagi semua peserta didiknya berdasarkan kepada kebutuhan peserta didik serta tanggung jawab dari guru BK. Menilai proses dan hasil kegiatan pelayanan bimbingan dan konseling serta melakukan penyesuaianpenyesuaian (mid-course adjustments) berdasarkan keputusan transaksional selama rentang proses bimbingan dan konseling dalam rangka memandirikan konseli (mind competence).Untuk melaksanan program layanan bimbingan dan koseling pasti memerlukan waktu yang cukup, dengan memiliki waktu yang cukup maka pelaksanaan bimbingan dan konseling memberikan bimbingan baik secara individu, kelompok maupun klasikal. Secara khusus bimbingan dan konseling bertujuan untuk membantu konseli agar dapat menyelesaikan tugas-tugas perkembangannya yang meliputi aspek pribadi-sosial, belajar dan karir.

2. Tugas guru bimbingan dan konseling

Pengembangan kehidupan pribadi, yaitu bidang pelayanan yang membantu peserta didik dalam memahami, menilai bakat dan minat. Pengembangan kehidupan sosial, yaitu bidang pelayanan yang membantu peserta didik dalam memahami dan menilai serta mengembangkan kemampuan hubungan sosial dan industrial yang harmonis, dinamis, berkeadilan dan bermartabat. Pengembangan kemampuan belajar, yaitu bidang pelayanan yang membantu peserta didik mengembangkan kemampuan belajar untuk mengikuti pendidikan sekolah/madrasah secara mandiri. Pengembangan karir, yaitu bidang pelayanan yang membantu peserta didik dalam memahami dan menilai informasi, serta memilih dan mengambil keputusan karir.

Bimbingan dan konseling diperuntukkan bagi semua siswa. Prinsip ini berarti bahwa bimbingan diberikan kepada semua siswa, baik yang tidak bermasalah maupun yang bermasalah, baik pria maupun wanita. Dalam hal ini pendekatan yang digunakan dalam bimbingan lebih bersifat preventif dan pengembangan dari pada penyembuhan (kuratif) 


\section{KESIMPULAN}

Guru

BK di

SMA

Muhammadiyah 1 Palangka Raya memberikan informasi-infornasi tentang layanan penempatan dan penyaluran yaitu menyalurkan pengembangan bakat, potensi yang ada, kemampuan dan minat yang dimiliki serta hoby yang ada dalam diri peserta didik dengan baik meskipun guru tersebut jarang masuk kelas terutama kalau ada mahasiswa BK yang PPL. Guru bimbingan dan konseling berperan sebagai motivator serta pembimbing dalam hal apa saja dan dalam memberikan layanan informasi tentang penjurusan penempatan dan penyaluran yang akan peserta didik ambil nantinya dan yang tertanam dalam diri peserta didik tentang pemahaman mereka baik dilingkungan sekolah maupun diluar lingkungan sekolah baik itu untuk kelas X, XI dan XII, dorongan dan semangat pembawaan dari guru bimbingan tersebut kepada peserta didik sehingga peserta didik merasa nyaman dan santai, itu terlihat dari sikap guru BK yang lebih terbuka, tidak acuh kepada peserta didiknya, kata-kata yang disampaikan mudah dimengerti dan diterima oleh peserta didik agar proses pelaksanaan layanan penempatan dan penyaluran dalam pemilihan jurusan peserta didik berjalan dengan baik.

\section{DAFTAR PUSTAKA}

Dimyati, Johni. 2013. Metodologi Penelitian pendidikan \& Aplikasinya pada Pendidikan Anak Usia Dini. Jakarta: Kencana Prenada Media Group.
Iskandar. 2008.Metodologi Penelitian dan Sosial (kuantitatif dan kualitatif). Jakarta: Gaung Persada Press.

Naskah Akademik ABKIN. 2007. Penataan Pendidikan Profesional Konselor dan Penyelenggaraan Bimbingan Konseling Dalam Jalur Pendidikan Formal.

Nurul Zuriah. 2006.

MetodologiPenelitian Sosial dan Pendidikan. Jakarta.

PrayitnodanErmanAmti. 2004. DasarDasarBimbingandankonseling.jaka rta: Rinekacipta.

Prayitno. 2004. Dasar dasarBimbinganKonseling. Jakarta: RinekaCipta.

Prayitno. 2004. Layanan Penempatan dan Penyaluran. Padang: FKIP Universitas Negeri Padang.

Rozhalina Ayu. 2015. Peran Guru Bimbingan dan Konseling Terhadap Belajar Siswa dalam Mengikuti Pelajaran. Jurnal Bimbingan Konseling. Volume 1. No 1. ISSN 2460. 9722

Sangadji \& Sopiah. 2010. Metodologi Penelitian. Malang: CV Andi Offset.

Suharsimi, Arikunto. 2008. Prosedur Penelitian Suatu pendekatan Praktek. Jakarta: Rineka Cipta.

Sutrisna. 2013. Bimbingan dan Konseling Pendidikan Formal, Nonformal dan Informal. Yogyakarta : CV. Andi Offset

Susanti. 2013. Pelaksanaan Layanan Penempatan Dan Penyaluran Oleh Guru Pembimbing Dalam Kegiatan Pegembangan Diri Ekstrakurikuler DI SMA Negeri 12 Padang. Jurnal 
Bimbingan dan konseling. Vol 2, No 12013.

Sukardi, Dewa, K. 2000. Pengantar

Pelaksanaan Layanan

Bimbingandan Konseling di

Sekolah. Jakarta: PT Rineka Cipta.

Suryabrata. 2010. Metodologi

Penelitian. Jakarta: PT Raja

Grafindo Persada.

Yusuf, Syamsu dan Juntika Nurishan.

2012. Landasan Bimbingan dan

Konseling. Program Pascasarjana

Universitas Pendidikan Indonesia.

Bandung: Remaja Rosdakarya 